\title{
PEMANFAATAN KARTU TANDA PENDUDUK ELEKTRONIK SEBAGAI ALTERNATIF OTENTIKASI (STUDI KASUS PADA SISTEM PAUS ID DI UNIVERSITAS PADJADJARAN)
}

\author{
Faishal Wahiduddin ${ }^{1)}$, Setiawan Hadi' ${ }^{2}$, Deni Setiana ${ }^{3)}$ \\ Email : ${ }^{1)}$ faishal12002@mail.unpad.ac.id, ${ }^{2)}$ setiawanhadi@unpad.ac.id, ${ }^{3)} \underline{\text { deni@unpad.ac.id }}$ \\ Program Studi Teknik Informatika, Departemen Ilmu Komputer, FMIPA Universitas Padjadjaran
}

\begin{abstract}
Near Field Communication Technology is a technology that allows communication between the device directly with the device close to one another. Near Field Communication technology has been embedded on a chip that is contained in the Electronic National Identity Card. With the NFC technology in the Electionic National Identity Card to maket he card as a smartcard. In this paper the author examines the use of Electronic National Identity Card as an alternative that can bes used to authenticate to a system called PAuS (Padjadjaran Authentification System) located at Universitas Padjadjaran. Implementation in the form of an Android-based mobile application that can display information in the form of student class schedules and academic transcripts with authentication using the Electronic Identity Card. The system has built-tested on 20 respondents students of Informatics in class of 2012, 2013, 2014 and 2015. Smartphone used consists of 9 different series, and as a result the entire smartphone can run the application utilizing Electronic National Identity Card as an alternative authentication on PAuS ID System.

Keywords - Near Field Communication, Electronic National Identity Card, Smartcard, Android, Padjadjaran Authentification System.

\section{ABSTRAK}

Teknologi NFC (Near Field Communication) merupakan sebuah teknologi yang memudahkan komunikasi antar perangkat secara langsung dengan mendekatkan perangkat yang satu dengan yang lain . Saat ini teknologi NFC telah dibenamkan pada chip yang terdapat dalam Kartu Tanda Penduduk Elektronik (e-KTP) sehingga menjadikan kartu tersebut sebagai sebuah smartcard. Pada paper ini penulis meneliti tentang pemanfaatan Kartu Tanda Penduduk Elektronik sebagai suatu alternatif yang bisa digunakan untuk melakukan otentikasi pada sistem PAuS (Padjadjaran Authentification System) yang terdapat di Universitas Padjadjaran. Implementasi berupa sebuah aplikasi mobile berbasis Android yang dapat menampilkan informasi mahasiswa berupa jadwal kuliah dan transkrip akademik dengan otentikasi menggunakan Kartu Tanda Penduduk Elektronik. Sistem yang telah dibangun diujicoba terhadap 20 orang responden mahasiswa Program Studi S-1 Teknik Informatika angkatan 2012, 2013, 2014 dan 2015. Smartphone yang digunakan terdiri dari 9 seri yang berbeda, dan hasilnya seluruh smartphone dapat menjalankan aplikasi dengan memanfaatkan Kartu Tanda Penduduk Elektronik sebagai alternatif Otentikasi pada Sistem PAuS ID.

Kata Kunci-Near Field Communication, Kartu Tanda Penduduk Elektronik, smartcard, Android, Padjadjaran Authentification System.
\end{abstract}

